\title{
Diagnostic Value of Symptoms for Pediatric SARS-CoV-2 Infection in a Primary Care Setting
}

Chien-Hsiang Weng, MD, MPH ${ }^{1,2}$, Wesley Wing Wah Butt, $\mathrm{MD}^{1,2}$, Meredith B. Brooks, $\mathrm{PhD}^{3}$, Claudia Clarke, $\mathrm{DO}^{2}$, Helen E. Jenkins, $\mathrm{PhD}^{4}$, Sabina D. Holland, $\mathrm{MD}^{5}$, Silvia S. Chiang, $\mathrm{MD}^{5,6}$

${ }^{1}$ Department of Family Medicine, Brown University Warren Alpert Medical School, Providence, RI

${ }^{2}$ Providence Community Health Centers, Providence, RI

${ }^{3}$ Department of Global Health and Social Medicine, Harvard Medical School, Boston, MA

${ }^{4}$ Department of Biostatistics, Boston University School of Public Health, Boston, MA

${ }^{5}$ Department of Pediatrics, Brown University Warren Alpert Medical School, Providence, RI

${ }^{6}$ Center for International Health Research, Rhode Island Hospital Providence, RI

Corresponding author: Silvia S. Chiang, MD

55 Claverick Street, Suite 101

Providence, RI 02903

E-mail: silvia_chiang@brown.edu

Telephone: 401-444-8360

Short title: Symptoms to Identify Pediatric COVID-19

Word count: 2479

Tables: 5

Figure: 1 


\section{Abstract}

\section{Purpose}

To evaluate the diagnostic value of symptoms used in the screening approaches by daycares and schools for identifying children and adolescents with possible SARS-CoV-2 infection, we designed a large observational study utilizing the data from primary care settings.

\section{Methods}

This cohort study included children and adolescents evaluated in a network of clinics in Rhode Island. Participants were age-stratified: 0-4, 5-11, and 12-17 years. We estimated the sensitivity, specificity, and area under the receiver operating curve (AUC) of individual symptoms and three symptom combinations: a probable case definition published by the Rhode Island Department of Health (RIDOH), and two novel combinations generated by different statistical approaches to maximize sensitivity and AUC. We evaluated the test characteristics of symptom combinations both with and without consideration of COVID-19 exposure.

\section{Results}

Two-hundred seventeen $(39.1 \%)$ of 555 participants were SARS-CoV-2-infected. Fever was more common among $0-4$ years-olds $(\mathrm{p}=0.002)$; older children more frequently reported fatigue $(\mathrm{p}=0.02)$ and anosmia or ageusia $(\mathrm{p}=0.047)$. In children $>5$ years old, anosmia or ageusia had 9498\% specificity. In all age groups, exposure history most accurately predicted infection. In combination with COVID-19 exposure history, various symptom combinations had sensitivity $>95 \%$ but specificity $<30 \%$. No individual symptom or symptom combination had AUC $\geq 0.70$.

\section{Conclusions}

Anosmia or ageusia in children $\geq 5$ years old and dyspnea in children 5-11 years old should raise providers' index of suspicion for COVID-19. However, our overall findings underscore the

Keywords: COVID-19, children, adolescent, Hispanic/Latinx, school health

\section{Abbreviations:}

SARS-CoV-2: severe acute respiratory syndrome coronavirus 2

COVID-19: coronavirus disease 2019

RT-PCR: reverse transcriptase polymerase chain reaction

NH: non-Hispanic

MI: body mass index

76 CART: combination generated by classification and regression tree

77 IQR: interquartile range

78 AUC: area under the receiver operating curve 
medRxiv preprint doi: https://doi.org/10.1101/2021.03.29.21254600; this version posted March 31, 2021. The copyright holder for this preprint (which was not certified by peer review) is the author/funder, who has granted medRxiv a license to display the preprint in perpetuity.

It is made available under a CC-BY 4.0 International license.

\section{Introduction}

82 Severe acute respiratory syndrome coronavirus 2 (SARS-CoV-2) has caused coronavirus disease

832019 (COVID-19) in 30 million people in the United States (U.S.) as of late March 2021.(1)

84 Children and adolescents account for $12.3 \%$ of reported COVID-19 cases in the U.S.(2) Most

85 children and adolescents have mild symptoms and are managed as outpatients(3-5); however,

86 few clinical studies of pediatric COVID-19 have been conducted in primary care settings.(6-8) A

87 clearer understanding of the diagnostic value of symptoms may have implications for the

88 symptom screening approaches used in daycares and schools for identifying children and

89 adolescents with possible SARS-CoV-2 infection.

90

91 To estimate the accuracy of symptoms for identifying pediatric SARS-CoV-2 infection, we

92 conducted this study of children and adolescents evaluated for COVID-19 in a network of clinics

93 in Providence, Rhode Island. We assessed the test characteristics of individual symptoms and

94 three symptom combinations: the Rhode Island Department of Health (RIDOH) probable case

95 definition,(9) which is used to screen students and daycare attendees for COVID-19, and two

96 novel combinations generated by statistical approaches to maximize sensitivity and area under

97 the receiver operating curve (AUC). As a secondary aim, we evaluated demographic and clinical

98 predictors of SARS-CoV-2 infection in our pediatric patients.

99

100 Methods

101

102 Setting 
medRxiv preprint doi: https://doi.org/10.1101/2021.03.29.21254600; this version posted March 31, 2021. The copyright holder for this preprint (which was not certified by peer review) is the author/funder, who has granted medRxiv a license to display the preprint in perpetuity.

It is made available under a CC-BY 4.0 International license.

104 This retrospective cohort study took place between March 20-June 22, 2020 before the massive

105 asymptomatic screening were recommended, at the Providence Community Health Centers

106 (PCHC), a network of ten clinics that provide primary care, urgent care, and specialty services.

107 PCHC serves approximately 60,000 patients, who are predominantly Hispanic. Ninety percent of

108 patients have household incomes under $200 \%$ of the federal poverty level.(10) Before the study

109 start date, PCHC clinicians implemented a standardized template to document symptoms and

110 exposure history of patients under evaluation for COVID-19. On April 1, 2020, RIDOH

111 recommended SARS-CoV-2 testing for anyone with exposure to or symptoms of COVID-19.(11)

112 Concurrently, local hospitals implemented pre-admission and pre-procedure COVID-19

113 screening.

\section{Participants}

117 We identified all PCHC patients who received SARS-CoV-2 reverse transcriptase polymerase

118 chain reaction (RT-PCR) testing on a nasopharyngeal sample on or before June 22, 2020, and

119 were younger than 18 years old at the time of the test. We included patients whose exposure and

120 symptoms were evaluated either before or after PCR testing. The latter group consisted of

121 patients tested in an emergency department or who underwent pre-procedure or pre-admission

122 COVID-19 screening, as long as their PCR result was documented in their PCHC chart and they

123 were evaluated with the standardized template during a follow-up visit.

\section{Data collection and variables}


medRxiv preprint doi: https://doi.org/10.1101/2021.03.29.21254600; this version posted March 31, 2021. The copyright holder for this preprint (which was not certified by peer review) is the author/funder, who has granted medRxiv a license to display the preprint in perpetuity.

It is made available under a CC-BY 4.0 International license.

127 Three authors (CW, WB, CC) manually abstracted the following variables: age, sex, self-

128 reported race/ethnicity, insurance status, body mass index (BMI)-for-age percentile, history of

129 asthma or allergic rhinitis, COVID-19 exposure history, presenting symptoms, and type of

130 encounter that led to SARS-CoV-2 testing (PCHC primary care, PCHC urgent care, emergency

131 department, procedure, or hospital admission). On the standardized template, the following

132 symptoms were marked as present or absent: new cough, dyspnea, new congestion/rhinorrhea,

133 myalgia, fever $\geq 100.4^{\circ} \mathrm{F}$, headache, sore throat, abdominal pain, nausea, vomiting, diarrhea,

134 anosmia or ageusia, and fatigue.

136 We categorized participants into age groups corresponding roughly with U.S. educational stages:

137 0-4 years (daycare/preschool), 5-11 years (elementary school), and 12-17 years (middle/high

138 school). Race/ethnicity was grouped into Hispanic, non-Hispanic (NH) Black, NH White, and

139 NH other (Asians, other Pacific Islanders, more than one race, and unknown). We used CDC

140 definitions to categorize BMI-for-age percentile.(12) Known COVID-19 exposure was self-

141 reported and defined as contact with a confirmed or suspected COVID-19 patient $\leq 14$ days prior

142 to SARS-CoV-2 testing.

144 Statistical analysis

146 We performed univariable binomial regression to compare demographic and clinical

147 characteristics between SARS-CoV-2-infected and uninfected participants. Variables that

148 differed between the two groups at a significance level of $\mathrm{p}<0.2$ were retained in a multivariable 
medRxiv preprint doi: https://doi.org/10.1101/2021.03.29.21254600; this version posted March 31, 2021. The copyright holder for this preprint (which was not certified by peer review) is the author/funder, who has granted medRxiv a license to display the preprint in perpetuity.

It is made available under a CC-BY 4.0 International license .

model. We checked for interactions on the multiplicative scale between known COVID-19

150 exposure and all other covariates.

152 For each age group, we calculated the sensitivity, specificity, and AUC of COVID-19 exposure

153 history and each symptom for identifying SARS-CoV-2 infection. Myalgia, headache, sore throat,

154 abdominal pain, nausea, and anosmia or ageusia were not assessed in children 0-4 years old due

155 to their lower ability to report these symptoms. We then evaluated the diagnostic value of three

156 symptom combinations: (1) the probable case definition published by RIDOH(9); (2) a

157 combination generated by a backward elimination approach; and (3) a combination generated by

158 classification and regression tree (CART) analysis. We evaluated the test characteristics of the

159 three symptom combinations both with and without consideration of COVID-19 exposure.

161 According to the RIDOH criteria, a probable COVID-19 case has one of the following: new

162 cough, shortness of breath, or anosmia or ageusia. A case also qualifies as probable COVID-19

163 by having at least two of the following: fever, chills, myalgia, headache, sore throat, nausea or

164 vomiting, diarrhea, fatigue, or new congestion or rhinorrhea.(9) As we did not collect

165 information on chills, we excluded this symptom in our analysis of the RIDOH criteria.

167 For each age group, we used a backward elimination approach to generate a symptom

168 combination that maximized specificity without sacrificing sensitivity. First, we calculated the

169 sensitivity, specificity, and AUC if any of the symptoms were present (the baseline combination).

170 Then, we manually removed symptoms one at a time, in order of ascending AUC. Symptoms 
medRxiv preprint doi: https://doi.org/10.1101/2021.03.29.21254600; this version posted March 31, 2021. The copyright holder for this preprint (which was not certified by peer review) is the author/funder, who has granted medRxiv a license to display the preprint in perpetuity.

It is made available under a CC-BY 4.0 International license.

171 with the same AUC were removed in order of ascending sensitivity. We selected the

172 combination with the highest specificity but the same sensitivity as the baseline combination.

173

174 We used CART analysis to identify the symptoms that best predicted SARS-CoV-2 infection in 175 each age group. In CART analysis, measures of predictive importance were assigned to each 176 symptom, entailing both marginal and interaction effects involving this variable. The data set 177 was then split into increasingly homogenous sub-groups, using improvement in the Gini gain

178 score, to identify the explanatory variable that gave the best discrimination between the two 179 outcome classes (COVID-19 vs. no COVID-19). Maximal trees were created and then pruned 180 based on relative misclassification costs, complexity, and parsimony. Ten-fold cross-validation 181 was performed, in which the whole data set was randomly split into learning and test data sets.

182 CART analysis was then applied to determine model performance and predictive accuracy in

183 these test sets, removing the need for a validation data set. We calculated discriminatory

184 properties of having at least one of the most important symptoms identified as nodes on the final 185 derived trees for each age group.

187 To determine the impact of recall bias from applying the standardized template after PCR testing,

188 we performed a sensitivity analysis restricted to participants who were evaluated for exposure

189 and symptoms before testing. We decided a priori to assess the diagnostic value of symptom

190 combinations only if there were meaningful differences in AUCs of exposure history and

191 individual symptoms.

192 
medRxiv preprint doi: https://doi.org/10.1101/2021.03.29.21254600; this version posted March 31, 2021. The copyright holder for this preprint (which was not certified by peer review) is the author/funder, who has granted medRxiv a license to display the preprint in perpetuity.

It is made available under a CC-BY 4.0 International license.

193 Twenty-two (4.0\%) participants with unknown race/ethnicity were grouped into the "NH other"

194 group and included in all analyses. BMI-for-age percentile-which is measured in children at

195 least two years old —was missing for 128 (23.1\%) participants, 96 of whom were younger than

196 two years. These participants were excluded from comparisons of BMI between SARS-CoV-2-

197 infected and uninfected children only. Four (0.7\%) participants had no data for one symptom;

198 they were excluded from regression models that examined the association between the number of

199 presenting symptoms and SARS-CoV-2 infection, as well as from calculations of sensitivity,

200 specificity, and AUC for the missing symptom only. There were no other missing data.

201

202 Analyses were conducted using R version 3.5.1 (R Statistical Computing, Vienna, Austria) and

203 Salford Systems Data Mining and Predictive Analytics Software version 8.0 (Salford Systems,

204 San Diego, California, U.S.). Sensitivity, specificity, and AUC estimates were calculated with

205 the reportROC package for R.(13)

206

207 Ethics

208

209 The PCHC Human Subjects Review Committee approved this study and waived informed

210 consent.

211

212 Results

213

214 Before June 22, 2020, SARS-CoV-2 PCR was performed in 803 individuals <18 years of age

215 who were registered as PCHC patients. We included 555 (69.1\%) who were evaluated using the 
medRxiv preprint doi: https://doi.org/10.1101/2021.03.29.21254600; this version posted March 31, 2021. The copyright holder for this preprint (which was not certified by peer review) is the author/funder, who has granted medRxiv a license to display the preprint in perpetuity.

It is made available under a CC-BY 4.0 International license.

216 standardized template. PCHC clinicians assessed $506(91.2 \%)$ participants in primary care and

217 five $(0.9 \%)$ in urgent care prior to PCR testing. Forty-four (7.9\%) participants were assessed by

218 PCHC clinicians after pre-procedure screening $(\mathrm{n}=10)$, hospital admission $(\mathrm{n}=21)$, and

219 emergency room visit $(n=13)$. The 248 excluded patients were tested at a PCHC specialty clinic

220 or a non-PCHC facility without subsequent evaluation using the standardized template

221 (Supplementary Material).

222

223 Of the 555 participants, 283 (51.0\%) had known COVID-19 exposure and at least one symptom;

$224183(33.0 \%)$ had at least one symptom but no known exposure; $56(10.1 \%)$ had known exposure

225 but no symptoms; and 33 (5.9\%) participants had neither symptoms nor known exposure. Two-

226 hundred eighty-nine (52.1\%) participants were tested after reopening on May 9. Median age was

2279 (IQR: 3.5-15) years; 293 (52.8\%) were female, 459 (82.7\%) were Hispanic, and 37 (6.7\%)

228 were uninsured (Table 1).

229

230

231

232

233

234

235

236

237

238 
Table 1: Patient Characteristics at Time of SARS-CoV-2 reverse transcriptase polymerase chain reaction

\begin{tabular}{|c|c|c|c|c|c|c|c|}
\hline & & or median & & Univariable rę & ssion & Multivariable re & ssion \\
\hline & $\begin{array}{c}\text { Uninfected } \\
(\mathrm{n}=338)\end{array}$ & $\begin{array}{l}\text { Infected } \\
(\mathrm{n}=217)\end{array}$ & $\begin{array}{c}\text { All } \\
(\mathrm{n}=555)\end{array}$ & $\mathrm{OR}(95 \% \mathrm{CI})$ & p-value & aOR (95\% CI) & p-value \\
\hline Age & $8(3-14)$ & $11(6-15)$ & $9(3.5-15)$ & $1.06(1.03,1.09)$ & $<0.001$ & $1.00(0.97,1.04)$ & 0.88 \\
\hline Female & $183(54.1)$ & $110(50.7)$ & $293(52.8)$ & $0.87(0.62,1.23)$ & 0.43 & & \\
\hline Race/ethnicity $^{\text {a }}$ & & & & & $<0.001$ & & \\
\hline Hispanic & $257(76.0)$ & $202(93.1)$ & $459(82.7)$ & $3.30(1.32,10.02)$ & 0.018 & $3.73(1.36,12.10)$ & 0.016 \\
\hline NH Black & $21(6.2)$ & $5(2.3)$ & $26(4.7)$ & Ref & & Ref & \\
\hline NH White & $24(7.1)$ & $6(2.8)$ & $30(5.4)$ & $1.05(0.28,4.12)$ & 0.94 & $1.91(0.43,8.78)$ & 0.40 \\
\hline NH Other & $36(10.7)$ & $4(1.8)$ & $40(7.2)$ & $0.47(0.11,1.95)$ & 0.29 & $0.60(0.14,2.75)$ & 0.51 \\
\hline Uninsured & $17(5.0)$ & $20(9.2)$ & $37(6.7)$ & $1.92(0.98,3.79)$ & 0.054 & $1.68(0.76,3.81)$ & 0.20 \\
\hline BMI category ${ }^{b}$ & & & & & 0.20 & & \\
\hline Underweight & $9(3.6)$ & $2(1.1)$ & $11(2.6)$ & $0.36(0.05,1.43)$ & & & \\
\hline Normal & $127(50.2)$ & $79(45.4)$ & $206(48.2)$ & Ref & & & \\
\hline Overweight & $40(15.8)$ & $37(21.3)$ & 77 (18.0) & $1.49(0.88,2.52)$ & & & \\
\hline Obese & 77 (30.4) & $56(32.2)$ & $133(31.1)$ & $1.17(0.75,1.82)$ & & & \\
\hline Asthma or allergic rhinitis & $70(20.7)$ & $40(18.4)$ & $110(19.8)$ & $0.87(0.56,1.33)$ & 0.51 & & \\
\hline Known COVID-19 exposure & $150(44.4)$ & $189(87.1)$ & $339(61.1)$ & $8.46(5.46,13.51)$ & $<0.001$ & $8.75(5.47,14.46)$ & $<0.001$ \\
\hline Number of COVID-19 symptoms & $2(1-3)$ & $3(2-4)$ & $2(1-4)$ & $1.32(1.20,1.46)$ & $<0.001$ & $1.32(1.18,1.47)$ & $<0.001$ \\
\hline Timing of PCR & & & & & & & \\
\hline
\end{tabular}




\begin{tabular}{|l|c|c|c|c|c|c|}
\hline During stay-at-home order & $158(59.4)$ & $108(40.6)$ & $266(47.9)$ & Ref & & \\
\hline After reopening & $180(62.3)$ & $109(37.7)$ & $289(52.1)$ & $0.89(0.63,1.25)$ & 0.49 & \\
\hline
\end{tabular}

${ }^{\text {a}}$ Of 459 Hispanics, 2 were Asian; 13, Black; 247, White, 85, >1 race; 3, Pacific Islander; 109, Unknown. Of 40 "Other," 9 were Asian; $8,>1$ race; 1, Pacific Islander; 22, Unknown.

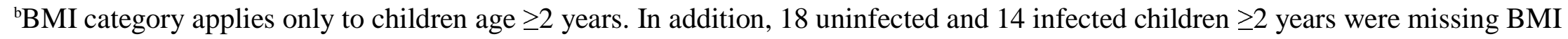
category; therefore, the percentages for the uninfected group and the infected group are calculated from 254 and 174 , respectively.

Abbreviations: BMI, body mass index; aOR, adjusted odds ratio; CI, confidence interval; IQR, interquartile range; OR, odds ratio; Ref, reference category.

Variables that were not included in the adjusted model have empty cells in the multivariable regression. 
medRxiv preprint doi: https://doi.org/10.1101/2021.03.29.21254600; this version posted March 31, 2021. The copyright holder for this preprint (which was not certified by peer review) is the author/funder, who has granted medRxiv a license to display the preprint in perpetuity.

It is made available under a CC-BY 4.0 International license .

253 Two-hundred seventeen (39.1\%) participants had SARS-CoV-2 infection. One infected

254 participant had neither known exposure nor symptoms. Asymptomatic infections occurred in

$2552 / 40(5.0 \%)$ 0-4 year-olds, 9/69 (13.0\%) 5-11 year-olds, and 9/108 (8.3\%) 12-17 year-olds

256 (Figure 1). Twenty-eight (12.9\%) SARS-CoV-2-infected participants had only one symptom

257 (Table 2).

259 Figure 1: Age-Stratified Clinical Presentation among 217 SARS-CoV-2-Positive Participants

260 Caption:

261 Myalgia, headache, sore throat, abdominal pain, nausea, and loss of taste/smell were not assessed

262 in children 0-4 years-old due to the lower reliability of these symptoms in this group. Bars show

$26395 \%$ confidence intervals. No children between the ages of 5-11 years presented with

264 nausea/vomiting.

265 Abbreviation: NA, not applicable.

267 Table 2: Participants Presenting with Only One Symptom

\begin{tabular}{|c|c|c|}
\hline & \multicolumn{2}{|c|}{ No. (\%) participants } \\
\hline & Uninfected $(\mathrm{n}=72)$ & Infected $(n=28)$ \\
\hline \multicolumn{3}{|l|}{ Symptom } \\
\hline Fever & $22(30.6)$ & $11(33.3)$ \\
\hline Fatigue & $2(2.8)$ & $0(0.0)$ \\
\hline Myalgia & $5(6.9)$ & $2(7.1)$ \\
\hline Headache & $5(6.9)$ & $3(10.7)$ \\
\hline Cough & $11(15.3)$ & $6(21.4)$ \\
\hline Dyspnea & $3(4.2)$ & $1(3.6)$ \\
\hline
\end{tabular}


medRxiv preprint doi: https://doi.org/10.1101/2021.03.29.21254600; this version posted March 31, 2021. The copyright holder for this preprint (which was not certified by peer review) is the author/funder, who has granted medRxiv a license to display the preprint in perpetuity.

It is made available under a CC-BY 4.0 International license .

\begin{tabular}{|c|c|c|}
\hline Sore throat & $3(4.2)$ & $3(10.7)$ \\
\hline Congestion/rhinorrhea & $9(12.5)$ & $0(0.0)$ \\
\hline Anosmia or ageusia & $2(2.8)$ & $0(0.0)$ \\
\hline Abdominal pain & $1(1.4)$ & $0(0.0)$ \\
\hline Nausea/vomiting & $4(5.6)$ & $1(3.6)$ \\
\hline Diarrhea & $5(6.9)$ & $24(85.7)$ \\
\hline Known COVID-19 exposure & $33(45.8)$ & \\
\hline
\end{tabular}

270 Children with a positive PCR were more likely to be older (11 vs. 8 years), have known COVID-

27119 exposure (87.1 vs 44.4\%), be Hispanic (93.1 vs. 76.0\%), and present with more symptoms (3

272 vs. 2 symptoms). Test positivity did not differ between participants evaluated before and after

273 reopening. The multivariable regression analyses showed consistent results (Table 1).

275 Stratifying the 217 children with COVID-19 by age, we observed fever more frequently among

276 children aged $0-4$ years $(\mathrm{p}=0.002)$. The prevalence of fatigue increased with age $(\mathrm{p}=0.02)$.

277 Adolescents 12-17 years old $(\mathrm{p}=0.047)$ were more likely to present with anosmia or ageusia

278 compared to children aged 5-11 years (Figure 1; Supplementary Material).

280 In all age groups, known COVID-19 exposure alone had the highest AUC for identifying SARS-

281 CoV-2 infection. No individual symptom or symptom combination had AUC >0.7 (Tables 3-5).

282 When exposure history was considered, all symptom combinations had 97-100\% sensitivity.

283 When exposure history was not considered, the RIDOH criteria and the combination generated

284 by backward elimination had the highest sensitivity: 95\% in 0-4 year-olds, 87\% in 5-11 year-olds, 285 and $92 \%$ in $12-17$ year-olds. All combinations had $<30 \%$ specificity. 
medRxiv preprint doi: https://doi.org/10.1101/2021.03.29.21254600; this version posted March 31, 2021. The copyright holder for this preprint (which was not certified by peer review) is the author/funder, who has granted medRxiv a license to display the preprint in perpetuity.

It is made available under a CC-BY 4.0 International license .

287 In children $<5$ years old, fever and cough were the individual symptoms with the highest

288 sensitivity at 70\% and 65\%, respectively (Table 3). In children 5-11 years old, no individual

289 symptom had $>50 \%$ sensitivity for COVID-19. Anosmia or ageusia had $98 \%$ specificity;

290 dyspnea had 95\% specificity (Table 4). Among adolescents 12-17 years old, cough and headache

291 were the individual symptoms with the highest sensitivity. Anosmia or ageusia had 94\%

292 specificity (Table 5).

293

294

295

296

297

298

299

300

301

302

303

304

305

306

307

308 
medRxiv preprint doi: https://doi.org/10.1101/2021.03.29.21254600; this version posted March 31, 2021. The copyright holder for this preprint (which was not certified by peer review) is the author/funder, who has granted medRxiv a license to display the preprint in perpetuity.

It is made available under a CC-BY 4.0 International license.

Table 3: Diagnostic Value of Symptom Screening in Children 0-4 Years of Age

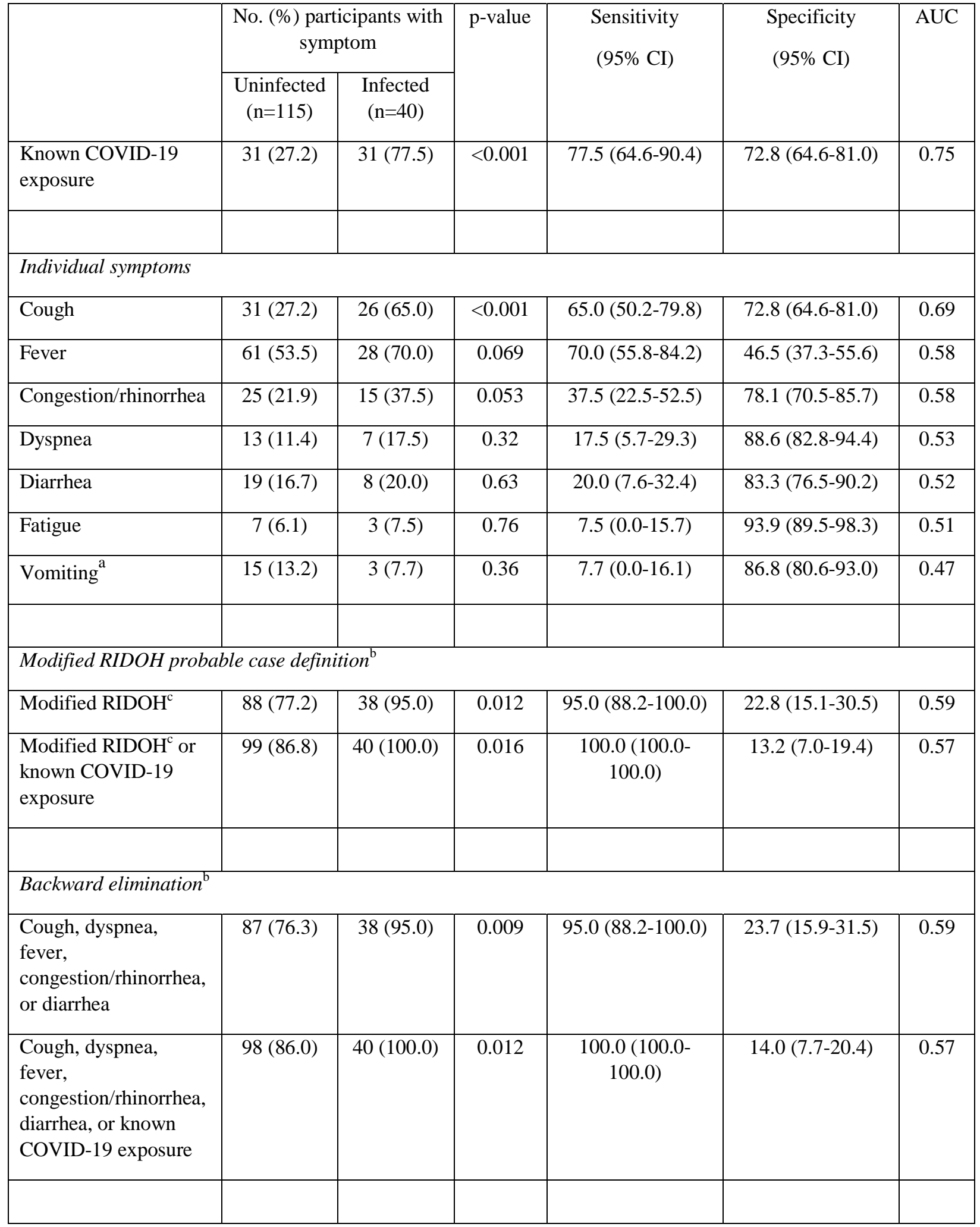


medRxiv preprint doi: https://doi.org/10.1101/2021.03.29.21254600; this version posted March 31, 2021. The copyright holder for this preprint (which was not certified by peer review) is the author/funder, who has granted medRxiv a license to display the preprint in perpetuity.

It is made available under a CC-BY 4.0 International license .

$312{ }^{\text {a }}$ There is a missing value for one participant.

$313{ }^{\mathrm{b}}$ The participant was considered to be positive for the symptom combination if at least one of the 314 features listed below was present.

$315{ }^{\mathrm{c}}$ Cough (new) or shortness of breath alone, or two of any of the following: fever, fatigue, 316 congestion/rhinorrhea (new), nausea/vomiting, and diarrhea. regression tree; CI, confidence interval; RIDOH, Rhode Island Department of Health. 
medRxiv preprint doi: https://doi.org/10.1101/2021.03.29.21254600; this version posted March 31, 2021. The copyright holder for this preprint (which was not certified by peer review) is the author/funder, who has granted medRxiv a license to display the preprint in perpetuity.

It is made available under a CC-BY 4.0 International license.

321 Table 4: Diagnostic Value of Symptom Screening in Children 5-11 Years of Age

322

\begin{tabular}{|c|c|c|c|c|c|c|}
\hline \multirow[t]{2}{*}{ Symptom } & \multicolumn{2}{|c|}{$\begin{array}{l}\text { No. (\%) participants with } \\
\text { symptom }\end{array}$} & \multirow[t]{2}{*}{ p-value } & \multirow[t]{2}{*}{ Sensitivity } & \multirow[t]{2}{*}{ Specificity } & \multirow[t]{2}{*}{ AUC } \\
\hline & $\begin{array}{l}\text { Uninfected } \\
\qquad(\mathrm{n}=99)\end{array}$ & $\begin{array}{c}\text { Infected } \\
(n=69)\end{array}$ & & & & \\
\hline $\begin{array}{l}\text { Known COVID-19 } \\
\text { exposure }\end{array}$ & $50(50.5)$ & $61(88.4)$ & $<0.001$ & $88.4(80.9-96.0)$ & $49.5(39.6-59.3)$ & 0.69 \\
\hline \multicolumn{7}{|l|}{ Individual symptoms } \\
\hline Headache & $26(26.3)$ & $34(49.3)$ & 0.002 & $49.3(37.5-61.1)$ & $73.7(65.1-82.4)$ & 0.62 \\
\hline Cough & $32(32.3)$ & $34(49.3)$ & 0.027 & $49.3(37.5-61.1)$ & $67.7(58.5-76.9)$ & 0.59 \\
\hline Fever & $34(34.3)$ & $34(49.3)$ & 0.052 & $49.3(37.5-61.1)$ & $65.7(56.3-75.0)$ & 0.58 \\
\hline Myalgia & $10(10.1)$ & $18(26.1)$ & 0.006 & $26.1(15.7-36.4)$ & $89.9(84.0-95.8)$ & 0.58 \\
\hline Sore throat & $23(23.2)$ & $26(37.7)$ & 0.043 & $37.7(26.2-49.1)$ & $76.8(68.4-85.1)$ & 0.57 \\
\hline Fatigue & $9(9.1)$ & $11(15.9)$ & 0.18 & $15.9(7.3-24.6)$ & $90.9(85.2-96.6)$ & 0.53 \\
\hline Anosmia or ageusia $^{a}$ & $2(2.0)$ & $5(7.2)$ & 0.098 & $7.2(1.1-13.4)$ & $98.0(95.2-100.0)$ & 0.53 \\
\hline Congestion/rhinorrhea & $26(26.3)$ & $19(27.5)$ & 0.85 & $27.5(17.0-38.1)$ & $73.7(65.1-82.4)$ & 0.51 \\
\hline Dyspnea & $5(5.1)$ & $3(4.3)$ & 0.83 & $4.3(0.0-9.2)$ & $94.9(90.6-99.3)$ & 0.50 \\
\hline Diarrhea & $9(9.1)$ & $5(7.2)$ & 0.67 & $7.2(1.1-13.4)$ & $90.9(85.2-96.6)$ & 0.49 \\
\hline Abdominal pain & $15(15.2)$ & $6(8.7)$ & 0.21 & $8.7(2.0-15.3)$ & 84.8 (77.8-91.9) & 0.47 \\
\hline Nausea/vomiting & $9(9.1)$ & $0(0.0)$ & 0.010 & $0.0(0.0-0.0)$ & $90.9(85.2-96.6)$ & 0.46 \\
\hline \multicolumn{7}{|c|}{ RIDOH probable case definition $^{\mathrm{b}}$} \\
\hline RIDOH criteria & $81(81.8)$ & $60(87.0)$ & 0.37 & $87.0(79.0-94.9)$ & $18.2(10.6-25.8)$ & 0.53 \\
\hline $\begin{array}{l}\text { RIDOH criteria or } \\
\text { known COVID-19 } \\
\text { exposure }\end{array}$ & $79(79.8)$ & $67(97.1)$ & 0.001 & $97.1(93.1-100.0)$ & $20.2(12.3-28.1)$ & 0.59 \\
\hline \multicolumn{7}{|l|}{ Backward elimination $^{\mathrm{b}}$} \\
\hline $\begin{array}{l}\text { Cough, fever, } \\
\text { headache, sore throat, } \\
\text { myalgia, } \\
\text { congestion/rhinorrhea, }\end{array}$ & $73(73.7)$ & $60(87.0)$ & 0.053 & $87.0(79.0-94.9)$ & $26.3(17.6-34.9)$ & 0.57 \\
\hline
\end{tabular}


medRxiv preprint doi: https://doi.org/10.1101/2021.03.29.21254600; this version posted March 31, 2021. The copyright holder for this preprint (which was not certified by peer review) is the author/funder, who has granted medRxiv a license to display the preprint in perpetuity.

\section{It is made available under a CC-BY 4.0 International license .}

\begin{tabular}{|c|c|c|c|c|c|c|}
\hline $\begin{array}{l}\text { fatigue, or anosmia or } \\
\text { ageusia }\end{array}$ & & & & & & \\
\hline $\begin{array}{l}\text { Known COVID-19 } \\
\text { exposure, cough, } \\
\text { fever, headache, sore } \\
\text { throat, or myalgia }\end{array}$ & $81(81.8)$ & $68(98.6)$ & $<0.001$ & $98.6(95.7-100.0)$ & $18.2(10.6-25.8)$ & 0.58 \\
\hline \multicolumn{7}{|l|}{$C A R T^{\mathrm{b}}$} \\
\hline $\begin{array}{l}\text { Headache, sore throat, } \\
\text { or cough }\end{array}$ & $57(57.6)$ & $54(78.3)$ & 0.005 & $78.3(68.5-88.0)$ & $42.4(32.7-52.2)$ & 0.60 \\
\hline $\begin{array}{l}\text { Myalgia, anosmia or } \\
\text { ageusia, headache, } \\
\text { sore throat, } \\
\text { congestion/rhinorrhea, } \\
\text { or known COVID-19 } \\
\text { exposure }^{\text {a }}\end{array}$ & $77(77.8)$ & $68(98.6)$ & $<0.001$ & $98.6(95.7-100.0)$ & $22.2(14.0-30.4)$ & 0.60 \\
\hline
\end{tabular}

${ }^{\mathrm{a}}$ There is a missing value for one participant.

${ }^{\mathrm{b}}$ The participant was considered to be positive for the symptom combination if at least one of the features listed below was present.

Abbreviations: AUC, area under the receiver operating curve; CART, classification and regression tree; CI, confidence interval; RIDOH, Rhode Island Department of Health. 
medRxiv preprint doi: https://doi.org/10.1101/2021.03.29.21254600; this version posted March 31, 2021. The copyright holder for this preprint (which was not certified by peer review) is the author/funder, who has granted medRxiv a license to display the preprint in perpetuity.

It is made available under a CC-BY 4.0 International license.

331 Table 5: Diagnostic Value of Symptom Screening in Adolescents 12-17 Years of Age 332

\begin{tabular}{|c|c|c|c|c|c|c|}
\hline \multirow[t]{2}{*}{ Symptom } & \multicolumn{2}{|c|}{$\begin{array}{l}\text { No. }(\%) \text { participants with } \\
\text { symptom }\end{array}$} & \multirow[t]{2}{*}{ p-value } & \multirow[t]{2}{*}{ Sensitivity } & \multirow[t]{2}{*}{ Specificity } & \multirow[t]{2}{*}{ AUC } \\
\hline & $\begin{array}{l}\text { Uninfected } \\
(\mathrm{n}=125)\end{array}$ & $\begin{array}{l}\text { Infected } \\
(n=108)\end{array}$ & & & & \\
\hline $\begin{array}{l}\text { Known COVID-19 } \\
\text { exposure }\end{array}$ & $69(55.2)$ & $97(89.8)$ & $<0.001$ & $89.8(84.1-95.5)$ & $44.8(36.1-53.5)$ & 0.67 \\
\hline \multicolumn{7}{|l|}{ Individual symptoms } \\
\hline Cough & $40(32.0)$ & $59(54.6)$ & $<0.001$ & $55.1(45.7-64.6)$ & $68.0(59.8-76.2)$ & 0.62 \\
\hline Headache & $52(41.6)$ & $63(58.3)$ & 0.011 & $58.3(49.0-67.6)$ & $58.4(49.8-67.0)$ & 0.58 \\
\hline Sore throat & $36(28.8)$ & $48(44.4)$ & 0.013 & $44.9(35.4-54.3)$ & $71.2(63.3-79.1)$ & 0.58 \\
\hline Congestion/rhinorrhea & $25(20.0)$ & $38(35.2)$ & 0.009 & $35.5(26.4-44.6)$ & $80.0(73.0-87.0)$ & 0.58 \\
\hline Myalgia & $32(25.6)$ & $40(37.0)$ & 0.060 & $37.0(27.9-46.1)$ & $74.4(66.7-82.1)$ & 0.56 \\
\hline Anosmia or ageusia $^{a}$ & $7(5.6)$ & $19(17.8)$ & 0.004 & $17.8(10.5-25.0)$ & $94.4(90.3-98.4)$ & 0.56 \\
\hline Fever & $35(28.0)$ & $41(38.0)$ & 0.11 & $38.3(29.1-47.5)$ & $72.0(64.1-79.9)$ & 0.55 \\
\hline Fatigue & $27(21.6)$ & $29(26.9)$ & 0.35 & $27.1(18.7-35.5)$ & $78.4(71.2-85.6)$ & 0.53 \\
\hline Diarrhea & $12(9.6)$ & $15(13.9)$ & 0.31 & $14.0(7.4-20.6)$ & $90.4(85.2-95.6)$ & 0.52 \\
\hline Dyspnea & $14(11.2)$ & $11(10.2)$ & 0.80 & $10.3(4.5-16.0)$ & $88.8(83.3-94.3)$ & 0.50 \\
\hline Abdominal pain & $20(16.0)$ & $7(6.5)$ & 0.024 & $6.5(1.9-11.2)$ & $84.0(77.6-90.4)$ & 0.45 \\
\hline Nausea/vomiting & $22(17.6)$ & $5(4.6)$ & 0.002 & $4.7(0.7-8.8)$ & $82.4(75.7-89.1)$ & 0.44 \\
\hline \multicolumn{7}{|c|}{ RIDOH probable case definition ${ }^{\mathrm{b}}$} \\
\hline RIDOH criteria & $98(78.4)$ & $99(91.7)$ & 0.005 & $91.7(86.5-96.9)$ & $21.6(14.4-28.8)$ & 0.57 \\
\hline $\begin{array}{l}\text { RIDOH criteria or } \\
\text { known COVID-19 } \\
\text { exposure }\end{array}$ & $104(83.2)$ & $107(99.1)$ & $<0.001$ & $99.1(97.3-100.0)$ & $16.8(10.2-23.4)$ & 0.58 \\
\hline \multicolumn{7}{|l|}{ Backward elimination $^{\mathrm{b}}$} \\
\hline $\begin{array}{l}\text { Cough, fever, } \\
\text { headache, sore throat, } \\
\text { myalgia, } \\
\text { congestion/rhinorrhea, }\end{array}$ & $90(72.0)$ & 99 (91.7) & $<0.001$ & 91.7 (86.5-96.9) & $28.0(20.1-35.9)$ & 0.60 \\
\hline
\end{tabular}


medRxiv preprint doi: https://doi.org/10.1101/2021.03.29.21254600; this version posted March 31, 2021. The copyright holder for this preprint (which was not certified by peer review) is the author/funder, who has granted medRxiv a license to display the preprint in perpetuity.

It is made available under a CC-BY 4.0 International license .

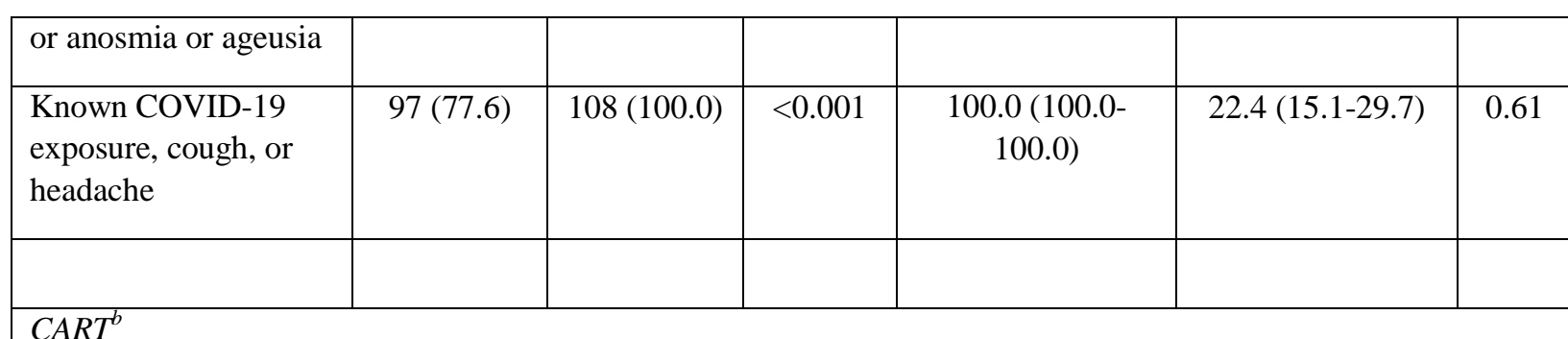

\begin{tabular}{|l|c|c|c|c|c|c|}
\hline $\begin{array}{l}\text { Cough, } \\
\text { nausea/vomiting, or } \\
\text { headache }\end{array}$ & $76(60.8)$ & $88(81.5)$ & $<0.001$ & $81.5(74.2-88.8)$ & $39.2(30.6-47.8)$ & 0.60 \\
\hline $\begin{array}{l}\text { Cough, fever, sore } \\
\text { throat, } \\
\text { congestion/rhinorrhea, } \\
\text { nausea/vomiting, or } \\
\text { known COVID-19 } \\
\text { exposure }\end{array}$ & $113(90.4)$ & $107(99.1)$ & 0.004 & $97.1(93.1-100.0)$ & $14.1(7.3-21.0)$ & 0.56 \\
\hline
\end{tabular}

$334{ }^{a}$ There is a missing value for two participants.

$335{ }^{\mathrm{b}}$ The participant was considered to be positive for the symptom combination if at least one of the 336 features listed below was present.

Abbreviations: AUC, area under the receiver operating curve; CART, classification and regression tree; CI, confidence interval; RIDOH, Rhode Island Department of Health. 
medRxiv preprint doi: https://doi.org/10.1101/2021.03.29.21254600; this version posted March 31, 2021. The copyright holder for this preprint (which was not certified by peer review) is the author/funder, who has granted medRxiv a license to display the preprint in perpetuity.

It is made available under a CC-BY 4.0 International license.

340 In the sensitivity analysis of participants evaluated with the standardized template before PCR

341 testing, the AUCs of exposure history and individual symptoms were similar to those calculated

342 for the entire study population, with differences of $\leq 0.02$ (Supplementarytable 1 Material).

\section{Discussion}

346 In this study, we assessed the diagnostic properties of symptoms for SARS-CoV-2 infection in a

347 large pediatric cohort, $>90 \%$ of whom presented to primary care and were evaluated with a

348 standardized symptom template before PCR testing. We identified symptom combinations with

349 high sensitivity, particularly in conjunction with COVID-19 exposure; however, all symptom

350 combinations had poor specificities. We failed to identify any individual symptom or symptom

351 combination with AUC >0.70, underscoring the importance of widely available SARS-CoV-2

352 testing with rapid turnaround.

354 The AUCs observed in our study likely are higher than in the general population for several

355 reasons. First, few study participants were asymptomatic, thus maximizing sensitivity of

356 symptoms. Second, our study took place in the spring and summer; specificities of symptoms are

357 expected to decrease further in the winter as more respiratory viruses circulate. Third, the

358 reliability of COVID-19 exposure history probably was higher in our cohort since many

359 participants were tested during a stay-at-home order. Therefore, they likely had few contacts and

360 were better able to stay informed of the infection status of their contacts. 
medRxiv preprint doi: https://doi.org/10.1101/2021.03.29.21254600; this version posted March 31, 2021. The copyright holder for this preprint (which was not certified by peer review) is the author/funder, who has granted medRxiv a license to display the preprint in perpetuity.

It is made available under a CC-BY 4.0 International license .

362 Reports of pediatric COVID-19 symptoms mostly include hospitalized participants.(3, 14-17)

363 One exception is a study conducted in Alberta, Canada, which used provincial databases to

364 assess the association of symptoms with SARS-CoV-2 PCR positivity.(8) This study found a

365 high positive predictive value for anosmia or ageusia; similarly, we observed a high specificity

366 of these symptoms. Our study differs in a few ways. First, in Alberta, the symptom questionnaire

367 was applied after test results were known, whereas symptoms were assessed before testing in

$368>90 \%$ of our cohort, reducing recall bias. Second, we age-stratified participants and detected

369 differences in COVID-19 presentation between age groups. These differences were similar to

370 those reported by the BRAVE study, which evaluated children with a close SARS-CoV-2-

371 infected contact(18): elementary school-aged children were most likely to have asymptomatic

372 COVID-19 (though the difference did not reach statistical significance in our cohort), the

373 youngest children were most likely to be febrile, and adolescents were more likely to report

374 anosmia or ageusia compared to elementary school-aged children.

375

376 Our findings have clinical and public health implications. The low AUCs we observed strongly

377 argue against the use of symptoms to diagnose pediatric COVID-19. However, anosmia or

378 ageusia in children $\geq 5$ years old and dyspnea in children 5-11 years old are highly specific, and

379 their presence should alert providers to quickly isolate and test the patient. Exposure history most

380 accurately predicted SARS-CoV-2 infection and should remain a cornerstone of quarantine

381 recommendations. Because of differences between our cohort and daycare and school attendees,

382 the diagnostic characteristics we observed may not be generalizable to that group. However, our

383 findings suggest that different age groups need distinct symptom screening criteria. Additionally, 
medRxiv preprint doi: https://doi.org/10.1101/2021.03.29.21254600; this version posted March 31, 2021. The copyright holder for this preprint (which was not certified by peer review) is the author/funder, who has granted medRxiv a license to display the preprint in perpetuity.

It is made available under a CC-BY 4.0 International license .

384 because of the low specificities of most symptoms, easily accessible tests with rapid turnaround

385 times are critical to minimize unnecessary absences.

387 With respect to the secondary aim of our study, we identified Hispanic ethnicity as an

388 independent risk factor for COVID-19 compared to the reference group of NH Black. Both the

389 BRAVE study and another study conducted in Washington, DC similarly found significantly

390 higher SARS-CoV-2 positivity in Hispanic children. $(18,19)$ Further investigation is needed to

391 clarify the contribution of various factors — including multigenerational or multi-family housing,

392 the inability to work from home, and language barriers - to these higher positivity rates.(20-24)

393 The DC study reported that NH Blacks also had higher positivity rates than NH Whites, but we

394 did not detect a difference between these groups, potentially due to insufficient statistical power.

396 This study had limitations. Data were collected early in the pandemic; however, symptoms are

397 not expected to change over the course of the pandemic, and the clinical and public health

398 implications of this study remain relevant and practical. As previously discussed, the AUCs of

399 exposure and symptoms that we observed may represent a "best case scenario," but this

400 possibility only strengthens the overarching message that symptoms are poorly predictive of

401 COVID-19.

402

403 Despite these limitations, our assessment of the diagnostic value of symptoms fills an important

404 gap in the pediatric COVID-19 literature. The poor AUCs we observed mean that symptoms

405 should not be used alone to identify pediatric SARS-CoV-2 infection, and underscore the

406 importance of widely available and efficient testing. 
medRxiv preprint doi: https://doi.org/10.1101/2021.03.29.21254600; this version posted March 31, 2021. The copyright holder for this preprint (which was not certified by peer review) is the author/funder, who has granted medRxiv a license to display the preprint in perpetuity.

It is made available under a CC-BY 4.0 International license .

408 The authors thank Jennifer Friedman and Philip Chan.

Conflict of Interest Disclosures (includes financial disclosures): None declared.

Data Sharing Statement: Deidentified individual participant data will not be made available.

\section{Author Contributions}

Prof. Weng conceptualized the study, collected the data, interpreted the results, drafted the manuscript, and reviewed the manuscript for content.

Prof. Butt conceptualized the study, collected the data, and reviewed the manuscript for content.

Dr. Brooks conducted the analyses, interpreted the results, and reviewed the manuscript for content.

Dr. Clarke conceptualized the study, collected the data, and reviewed the manuscript for content.

Prof. Jenkins provided input for analyses, interpreted the results, and reviewed the manuscript for content.

Prof. Holland conceptualized the study, and reviewed the manuscript for content.

Prof. Chiang conceptualized the study, conducted the analyses, interpreted the results, drafted the manuscript, and reviewed the manuscript for content.

All authors approved the final manuscript as submitted and agree to be accountable for all aspects of the work. 
medRxiv preprint doi: https://doi.org/10.1101/2021.03.29.21254600; this version posted March 31, 2021. The copyright holder for this preprint (which was not certified by peer review) is the author/funder, who has granted medRxiv a license to display the preprint in perpetuity.

It is made available under a CC-BY 4.0 International license .

\section{References}

1. Johns Hopkins University School of Medicine. COVID-19 dashboard by the Center for Systems Science and Engineering (CSSE) at Johns Hopkins University (JHU). [Available from: https://coronavirus.jhu.edu/.

2. American Academy of Pediatrics and the Children's Hospital Association. Children and COVID-19: State Data Report [updated December 21, 2020. Available from:

https://services.aap.org/en/pages/2019-novel-coronavirus-covid-19-infections/children-andcovid-19-state-level-data-report/.

3. Castagnoli R, Votto M, Licari A, Brambilla I, Bruno R, Perlini S, et al. Severe Acute Respiratory Syndrome Coronavirus 2 (SARS-CoV-2) Infection in Children and Adolescents: A Systematic Review. JAMA Pediatr. 2020.

4. Dong Y, Mo X, Hu Y, Qi X, Jiang F, Jiang Z, et al. Epidemiology of COVID-19 Among Children in China. Pediatrics. 2020;145(6).

5. Shane AL, Sato AI, Kao C, Adler-Shohet FC, Vora SB, Ery J, et al. A Pediatric Infectious Disease Perspective of SARS-CoV-2 and COVID-19 in Children. J Pediatric Infect Dis Soc. 2020.

6. Struyf T, Deeks JJ, Dinnes J, Takwoingi Y, Davenport C, Leeflang MM, et al. Signs and symptoms to determine if a patient presenting in primary care or hospital outpatient settings has COVID-19 disease. Cochrane Database Syst Rev. 2020;7:CD013665.

7. Assaker R, Colas AE, Julien-Marsollier F, Bruneau B, Marsac L, Greff B, et al. Presenting symptoms of COVID-19 in children: a meta-analysis of published studies. Br J Anaesth. 2020;125(3):e330-e2.

8. King JA, Whitten TA, Bakal JA, McAlister FA. Symptoms associated with a positive result for a swab for SARS-CoV-2 infection among children in Alberta. CMAJ. 2020.

9. Rhode Island Department of Health. Outbreak Response Protocols: Pre K-12. Guidance for COVID-19 outbreak response in Pre K-12 [updated November 19, 2020. Available from: https://reopeningri.com/wp-content/uploads/2020/08/2020-09-14 K-12-Playbook edited v2.pdf. 10. Providence Community Health Center Facts and Figures [Available from:

https://www.providencechc.org/about-2/facts-and-figures.

11. Rhode Island Department of Health. COVID-19 Information. [Available from: https://health.ri.gov/diseases/ncov2019/.

12. Centers for Disease Control and Prevention. About Child \& Teen BMI [updated June 29, 2020. Available from:

https://www.cdc.gov/healthyweight/assessing/bmi/childrens_bmi/about_childrens_bmi.html.

13. Du ZaH, Y. reportROC: An Easy Way to Report ROC Analysis. R package version 3.5 ed2020.

14. Team CC-R. Coronavirus Disease 2019 in Children - United States, February 12-April 2, 2020. MMWR Morb Mortal Wkly Rep. 2020;69(14):422-6.

15. Swann OV, Holden KA, Turtle L, Pollock L, Fairfield CJ, Drake TM, et al. Clinical characteristics of children and young people admitted to hospital with covid-19 in United Kingdom: prospective multicentre observational cohort study. BMJ. 2020;370:m3249. 16. Hoang A, Chorath K, Moreira A, Evans M, Burmeister-Morton F, Burmeister F, et al. COVID-19 in 7780 pediatric patients: A systematic review. EClinicalMedicine. 2020;24:100433. 
medRxiv preprint doi: https://doi.org/10.1101/2021.03.29.21254600; this version posted March 31, 2021. The copyright holder for this preprint (which was not certified by peer review) is the author/funder, who has granted medRxiv a license to display the preprint in perpetuity.

It is made available under a CC-BY 4.0 International license.

17. Viner RM, Ward JL, Hudson LD, Ashe M, Patel SV, Hargreaves D, et al. Systematic review of reviews of symptoms and signs of COVID-19 in children and adolescents. Arch Dis

497 Child. 2020.

18. Hurst JH, Heston SM, Chambers HN, Cunningham HM, Price MJ, Suarez L, et al. SARS-CoV-2 Infections Among Children in the Biospecimens from Respiratory Virus-Exposed 500 Kids (BRAVE Kids) Study. Clin Infect Dis. 2020.

501 19. Goyal MK, Simpson JN, Boyle MD, Badolato GM, Delaney M, McCarter R, et al. 502 Racial/Ethnic and Socioeconomic Disparities of SARS-CoV-2 Infection Among Children.

503 Pediatrics. 2020.

504 20. Weng CH, Saal A, Chan PA. High Prevalence of SARS-CoV-2 Infection Among the 505 Uninsured Hispanic/Latino Population: a Retrospective Cohort Study. J Gen Intern Med. 2020.

506 21. Page KR, Venkataramani M, Beyrer C, Polk S. Undocumented U.S. Immigrants and 507 Covid-19. N Engl J Med. 2020;382(21):e62.

508 22. Yancy CW. COVID-19 and African Americans. JAMA. 2020.

509 23. Figueroa JF, Wadhera RK, Lee D, Yeh RW, Sommers BD. Community-Level Factors 510 Associated With Racial And Ethnic Disparities In COVID-19 Rates In Massachusetts. Health 511 Aff (Millwood). 2020:101377hlthaff202001040.

512 24. Weng CH, Saal A, McGuire DC, Chan PA. Persistently high SARS-CoV-2 positivity rate 513 and incidence for Hispanic/Latinos during state reopening in an urban setting: a retrospective 514 cohort study. Epidemiol Infect. 2021;149:e25. 
medRxiv preprint doi: https://doi.org/10.1101/2021.03.29.21254600; this version posted March 31, 2021. The copyright holder for this preprint (which was not certified by peer review) is the author/funder, who has granted medRxiv a license to display the preprint in perpetuity. 
medRxiv preprint doi: https://doi.org/10.1101/2021.03.29.21254600; this version posted March 31, 2021. The copyright holder for this preprint (which was not certified by peer review) is the author/funder, who has granted medRxiv a license to display the preprint in perpetuity.

It is made available under a CC-BY 4.0 International license. 


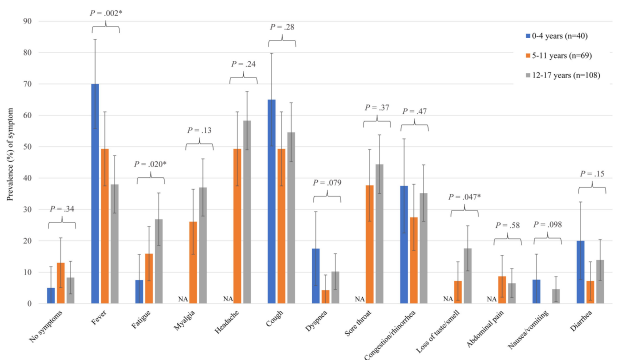

